\title{
Anti-apoptotic effects of phyllanthin against alcohol- induced liver cell death
}

\author{
Wanida Sukketsiri ${ }^{1 *}, K_{i t j a}$ Sawangjaroen ${ }^{1}$ and Supita Tanasawet ${ }^{2}$ \\ ${ }^{1}$ Department of Pharmacology, ${ }^{2}$ Department of Anatomy, Faculty of Science, Prince of Songkla University, Hat Yai, Songkhla \\ 90110, Thailand \\ *For correspondence: Email: wanida.su@psu.ac.th; Tel: +66 74 288171; Fax: +66 74446678
}

\begin{abstract}
Purpose: To evaluate the anti-apoptotic effect of phyllanthin on alcohol-induced liver cell death in HepG2 cells alone and in co-culture with human monocytic (THP-1) differentiated macrophage cells. Methods: Cell viability was determined by 3-(4,5-dimethylthiazol-2-yl)-2,5-diphenyltetrazolium bromide (MTT) assay. The cells were pretreated with 1, 5 and $10 \mu \mathrm{M}$ phyllanthin for $24 \mathrm{~h}$ followed by $1300 \mathrm{mM}$ alcohol for HepG2 cells and $2000 \mathrm{mM}$ alcohol for the co-cultured cells. Thereafter, intracellular reactive oxygen species (ROS), mitochondrial membrane potential (MMP) changes, apoptotic cell death and caspase-3/7 activities were assessed.

Results: Alcohol exposure significantly increased intracellular ROS generation $(p<0.001)$, decreased MMP changes $(p<0.001)$, increased the number of apoptotic and necrotic cells $(p<0.001)$ and also induced higher caspase-3/7 activity $(p<0.001)$ in the co-culture with THP-1 differentiated macrophage cells than in HepG2 cells alone. Pretreatment of HepG2 cells and co-cultured cells with phyllanthin for $24 \mathrm{~h}$ prior to alcohol exposure significantly decreased intracellular production of ROS $(p<0.001)$ and also increased the change in MMP $(p<0.001)$ as well as caused a decrease in the number of apoptotic and necrotic cells $(p<0.001)$, but inhibited caspase-3/7 activity $(p<0.001)$.

Conclusion: The results indicate that phyllanthin treatment may have a significant therapeutic effect on alcohol-related liver diseases.
\end{abstract}

Keywords: Hepatoprotective, Liver diseases, Human monocytic cells, Reactive oxygen species, Apoptosis, Co-culture, Mitochondrial membrane potential

Tropical Journal of Pharmaceutical Research is indexed by Science Citation Index (SciSearch), Scopus, International Pharmaceutical Abstract, Chemical Abstracts, Embase, Index Copernicus, EBSCO, African Index Medicus, JournalSeek, Journal Citation Reports/Science Edition, Directory of Open Access Journals (DOAJ), African Journal Online, Bioline International, Open-J-Gate and Pharmacy Abstracts

\section{INTRODUCTION}

Alcohol consumption is a major cause of chronic liver disease which may develop after years of chronic alcohol consumption and results in high morbidity and mortality rates [1]. Moreover, hepatocyte apoptosis is significantly raised in alcohol hepatitis patients and correspond with the severity of the disease and hepatic fibrosis [2]. Alcohol-induced liver injury is a complex process and is dependent upon the interplay of multiple cell types in the liver. It is of interest, that hepatic macrophages (Kupffer cells) play a pivotal role in the pathogenesis of alcoholinduced liver cell death [3]. Kupffer cells are activated following alcohol consumption to generate various toxic mediators such as oxygen radicals, tumor necrosis factor alpha (TNF- $\alpha$ ), interleukin and prostaglandins $[4,5]$ contribute to hepatocyte dysfunction, apoptosis and the necrosis of hepatocytes $[6,7]$.

Current alcohol liver disease therapy using modern medical practices is often restricted in its 
efficacy, has high adverse events and is costly [1]. So, there is a need to identify potential therapeutic agents that will lower the incidence of adverse effects. Therefore, medicinal plants are being used for alternative and complementary therapies. Preparations from Phyllanthus amaras Schum. et Thonn have been used extensively in traditional medicine particularly for the treatment of liver diseases [8]. In addition, phyllanthin, the active compound of $P$. amarus is reported to be an active antioxidant [9], anti-inflammatory $[10,11]$ and hepatoprotective properties [9]. The mechanism of the hepatoprotective activity of phyllanthin has been shown to effectively facilitate the recovery of its antioxidant capability including the level of total glutathione, the activities of superoxide dismutase and glutathione reductase $[12,13]$. However, the effect of phyllanthin on alcohol-induced cell death has not been clarified.

Hence, the aim of this study was to investigate the efficacy of phyllanthin in preventing in vitro HepG2 alone and a co-culture of HepG2 with THP-1 differentiated macrophage cells after injury induced by exposure to alcohol.

\section{EXPERIMENTAL}

\section{Chemicals and cell culture}

Phyllanthin was isolated and purified from the fresh aerial part of $P$. amarus and identified by IR spectrum and HPLC, as previously reported [12]. The purities of the phyllanthin preparations were compared with standard references (Chromadex, Inc., USA), and were at least $98 \%$ pure [12]. THP-1 cells were obtained from the Cell Line Service, Heidelberg, Germany, and human hepatocarcinoma (HepG2) cells were kindly provided by $\mathrm{Dr}$ Wisit Tangkeangsirisin, Department of Biopharmacy, Faculty of Pharmacy, Silpakorn University, Thailand.

HepG2 cells were cultured in complete Dulbecco's modified Eagle's medium (DMEM) containing supplemented nutrients and essential condition (GIBCO, Invitrogen Corporation, USA). Before use, THP-1 cells were induced to differentiate into macrophage-like cells using 100 $\mathrm{ng} / \mathrm{mL}$ of phorbol 12-myristate 13-acetate (Sigma-Aldrich, USA). The cells were cultured for $48 \mathrm{~h}$ to allow final differentiation into macrophages [14]. A co-culture of HepG2 and THP-1 differentiated macrophage cells at a ratio of 2:1 was grown in complete RPMI-1640 medium supplemented with nutrients and essential condition.

\section{Cytotoxicity assay}

HepG2 cells $\left(1.5 \times 10^{4}\right.$ cells/well) and co-cultured with THP-1 differentiated macrophage cells were treated with alcohol at concentrations of 0-2000 $\mathrm{mM}$ and further incubated for $4 \mathrm{~h}$. In addition, both cell types were treated with phyllanthin at various concentrations $(0-50 \mu \mathrm{M})$ for $24 \mathrm{~h}$. Thereafter, cell viability was determined using a colorimetric MTT (Sigma-Aldrich, USA) assay [15]. Briefly, the MTT solution was added at a final concentration of $0.5 \mathrm{mg} / \mathrm{mL}$ and the optical density was measured at $570 \mathrm{~nm}$ using a microplate reader (Bio-tex, USA).

\section{Intracellular reactive oxygen species (ROS) production}

Intracellular ROS production in the HepG2 and co-culture cells were assayed through the oxidation of 2',7'-dichlorofluorescein diacetate (DCFH-DA) (Sigma-Aldrich, USA) [16]. Briefly, both cell types were cultured at a density of $3 x$ $10^{4}$ cells/well. Before alcohol exposure, cells were pretreated with phyllanthin at concentrations of $0,1,5$ and $10 \mu \mathrm{M}$ for $24 \mathrm{~h}$. Then, cells were washed and incubated with 20 $\mu \mathrm{M}$ of DCFH-DA for $45 \mathrm{~min}$ followed by $1300 \mathrm{mM}$ alcohol for the HepG2 cells and $2000 \mathrm{mM}$ alcohol for the co-cultured cells for $4 \mathrm{~h}$. The fluorescence intensity was measured using a fluorescence microplate reader (Bio-tex, USA) at an excitation wavelength of $485 \mathrm{~nm}$ and emission wavelength of $530 \mathrm{~nm}$.

\section{Mitochondrial membrane potential (MMP) analysis}

The MMP change was analyzed using the MMP assay kit (Abcam, USA), according to the manufacturer's instructions. In brief, both sets of cells $\left(3 \times 10^{4}\right.$ cells/well) were pretreated with phyllanthin $(0-10 \mu \mathrm{M})$ for $24 \mathrm{~h}$ and then incubated with $1300 \mathrm{mM}$ alcohol for the HepG2 cells and $2000 \mathrm{mM}$ alcohol for the co-cultured cells for $4 \mathrm{~h}$. The fluorescence intensity was measured using a fluorescence microplate reader (Bio-tex, USA) at an excitation wavelength of $549 \mathrm{~nm}$ and emission wavelength of $575 \mathrm{~nm}$. Tetramethyl rhodamine ethyl ester (TMRE) positive cell was expressed as \% of control fluorescence signal from the treated and untreated samples.

\section{Apoptosis and necrosis assay}

Apoptosis and necrosis were determined using a fluorescent DNA stain with Hoechst 33342 and propidium iodide (PI) (Cell Signaling, USA). The cells were stained with $10 \mu \mathrm{g} / \mathrm{mL}$ Hoechst 33342 
and $\mathrm{PI}$ for $30 \mathrm{~min}$ at $37^{\circ} \mathrm{C}$. Cells were examined using a fluorescence microscope (Olympus IX71, Japan). The data was presented in terms of $\%$ cell death.

\section{Evaluation of caspase-3/7 activity}

Caspase- $3 / 7$ activity was measured using the Caspase-Glo assay kit (Promega, USA), according to the manufacturer's instructions. Briefly, both of the cell types were cultured in a 96-well white plate at a density of $1 \times 10^{4}$ cells/well and pretreated with $(0-10 \mu \mathrm{M})$ phyllanthin for $24 \mathrm{~h}$, the cells were then treated with alcohol for $4 \mathrm{~h}$. The luminescence intensity was measured using a luminometer (Applied Biosystems, USA) with parameters of a 1 minute lag time and $0.5 \mathrm{sec} /$ well-read time.

\section{Statistical analysis}

All data are presented as a mean \pm standard error of the mean (SEM, $n=4)$. One-way analysis of variance (ANOVA) with Tukey's test was used to test differences in mean values among the groups. $P<0.05$ was considered statistically significant. The data were analyzed using SPSS version 16.

\section{RESULTS}

Cell morphology and cytotoxicity of phyllanthin and alcohol on HepG2 cells and co-cultured cells

Alcohol significantly decreased the viability of the HepG2 cells and the co-cultured cells in a concentration-dependent manner with morphological changes (the cells rounded up, lose contact with their neighbors and shrank) (Figure 1A). The $50 \%$ inhibitory concentrations $\left(\mathrm{IC}_{50}\right)$ of alcohol in the HepG2 cells and cocultured cells were $1225.42 \pm 27.56$ and 1950.20 $\pm 72.27 \mathrm{mM}$, respectively. In addition, our results indicated that phyllanthin $(1-50 \mu \mathrm{M})$ by itself did not affect cell viability or morphology of any of the cell types after $24 \mathrm{~h}$ of treatment (Figure 1B).

\section{Effect of phyllanthin against alcohol-induced ROS production in HepG2 and co-cultured cells}

Without phyllanthin pretreatment, alcohol produced a significant increase in the intracellular ROS production to $122.66 \pm 2.56$ and $126.43 \pm 4.52 \%$ of the control in the HepG2 and co-cultured cells, respectively after $4 \mathrm{~h}$ of alcohol exposure (Figure 2). In HepG2 cells, we found that phyllanthin at a dose of 1,5 and 10 $\mu \mathrm{M}$ could significantly attenuate ROS generation to $111.04 \pm 2.27,105.22 \pm 0.92$, and $98.50 \pm$ $3.26 \%$ of the control, respectively (Figure 2 ). In the co-cultured cells, a high concentration of phyllanthin $(5$ and $10 \mu \mathrm{M})$ significantly decreased the intracellular ROS production to $112.89 \pm 1.25$ and $108.61 \pm 0.77 \%$ of the control, respectively (Figure 2). In the hepatocytes cultured alone, these results indicated that alcohol caused an elevation in the intracellular ROS level; however, it was significantly reduced by phyllanthin pretreatment. On the other hand, only a high concentration of phyllanthin could prevent the alcohol-induced ROS generation in the cocultured cells. Hence it might be the macrophages that induced the high ROS production.
(A)

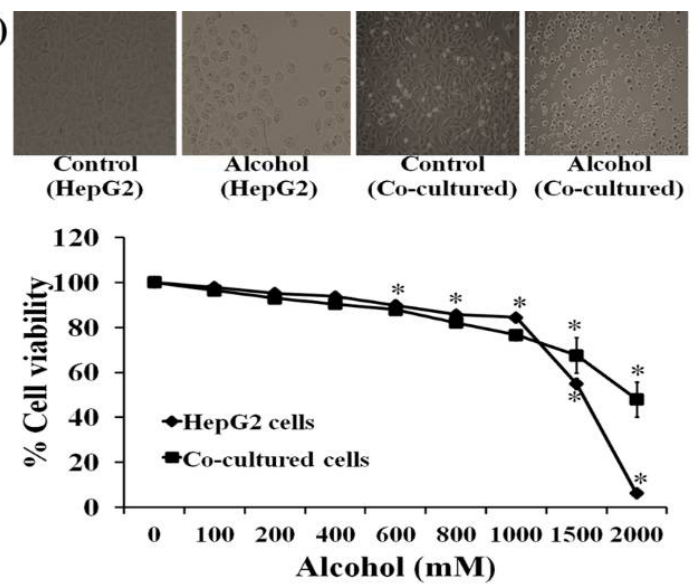

(B)

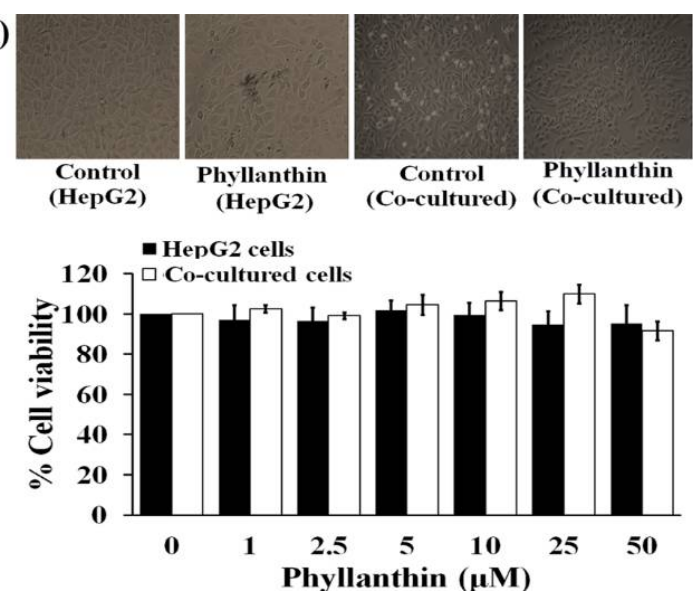

Figure 1: Cytotoxicity of alcohol and phyllanthin on HepG2 cells and co-cultured cells. (A) Light microscope examination (scale bar $=100 \mu \mathrm{m}$ ) and cytotoxicity test after treatment with various concentrations $(0-2000 \mathrm{mM}$ ) of alcohol for $4 \mathrm{~h}$ in HepG2 cells and co-cultured cells. (B) HepG2 cells and co-cultured cells were treated with various concentrations $(0-50 \mu \mathrm{M})$ of phyllanthin for $24 \mathrm{~h}$. Data shown are mean values \pm SEM of four independent experiments; ${ }^{*} p<0.001$ compared to control 


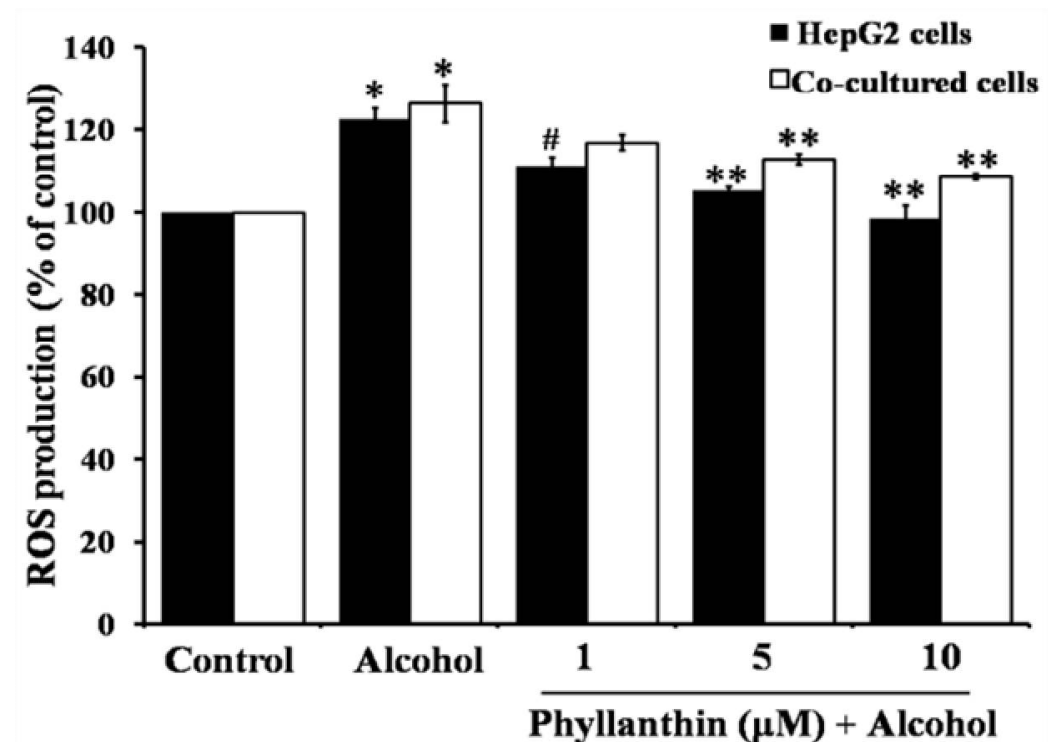

Figure 2: Effect of alcohol on the intracellular generation of ROS and its inhibition by phyllanthin pretreatment in HepG2 cultured alone and co-cultured with THP-1 differentiated macrophage cells. HepG2 cells cultured alone and co-cultured cells were pretreated with various concentrations $(0-10 \mu \mathrm{M})$ of phyllanthin for $24 \mathrm{~h}$ before exposure to alcohol for $4 \mathrm{~h}$. Data shown are mean values \pm SEM of four independent experiments; ${ }^{*} p<0.001$ compared to control; $\# p<0.01$ compared to alcohol; ${ }^{* *} p<0.001$ compared to alcohol

\section{Effect of phyllanthin against alcohol-induced MMP change in HepG2 and co-cultured cells}

Exposure to alcohol for $4 \mathrm{~h}$ significantly decreased the percentage of TMRE positive cells to $70.24 \pm 2.31$ and $60.52 \pm 0.36 \%$ of the control in HepG2 cells and the co-cultured cells, respectively (Figure 3 ). The percentage of the TMRE positive cells was significantly increased in a concentration-dependent manner when the cells were pretreated with $(1-10 \mu \mathrm{M})$ phyllanthin before alcohol exposure of the HepG2 cells (Figure 3). In the co-cultured cells, pretreatment of phyllanthin only at its highest concentration $(10 \mu \mathrm{M})$ significantly increased the percentage of TMRE positive cells (Figure 3). It can be inferred from the obtained results that phyllanthin could significantly reduce the alcohol-induced mitochondrial dysfunction.

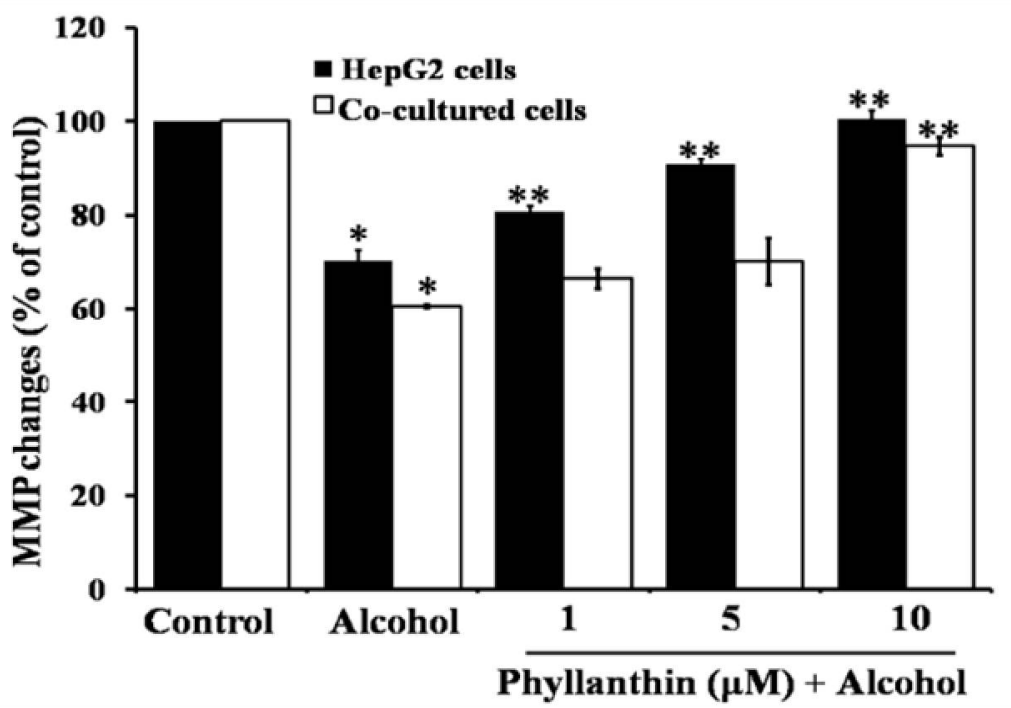

Figure 3: Effect of alcohol on the mitochondrial membrane potential in HepG2 cells and co-cultured with THP-1 differentiated macrophage cells. HepG2 cells and co-cultured cells were pretreated with various concentrations $(1,5$ and $10 \mu \mathrm{M})$ of phyllanthin for $24 \mathrm{~h}$ before exposure to alcohol for $4 \mathrm{~h}$; MMP was measured by the TMRE assay. Data shown are mean \pm SEM $(n=4) ;{ }^{*} p<0.001$ compared to the control; ${ }^{* *} p<0.001$ compared to the alcohol without phyllanthin pretreatment 
(A)

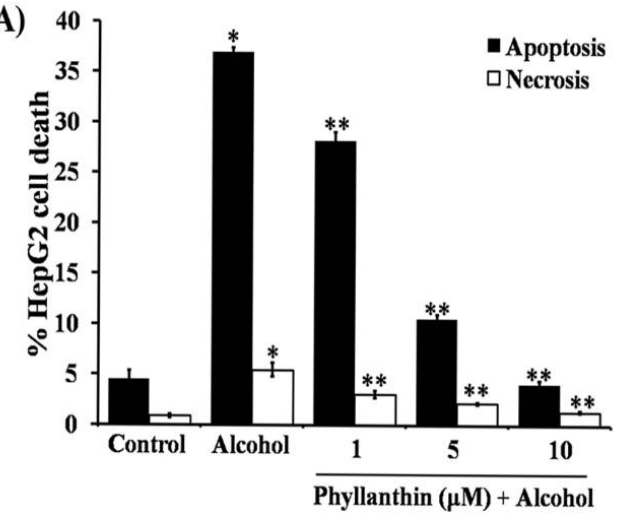

(B)

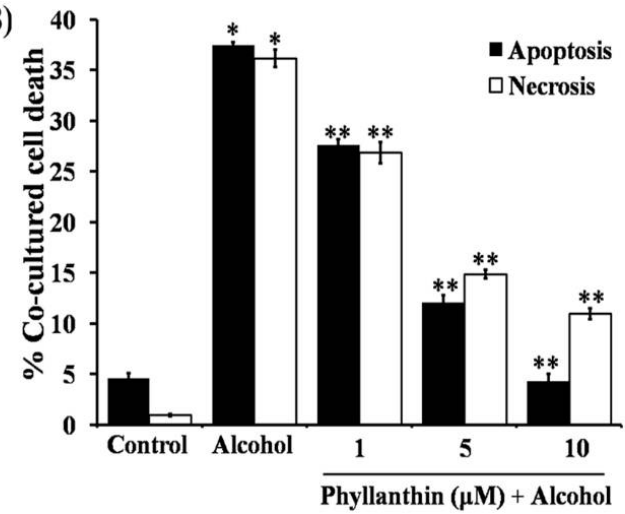

Figure 4: Effect of phyllanthin against alcohol-induced apoptotic and necrotic cell death in HepG2 cells and cocultured cells. (A) Apoptotic and necrotic cells in HepG2 cells (\%); (B) Apoptotic and necrotic cells in the cocultured cells (\%); ${ }^{*} p<0.001$ compared to the control; ${ }^{* *} p<0.001$ compared to the alcohol

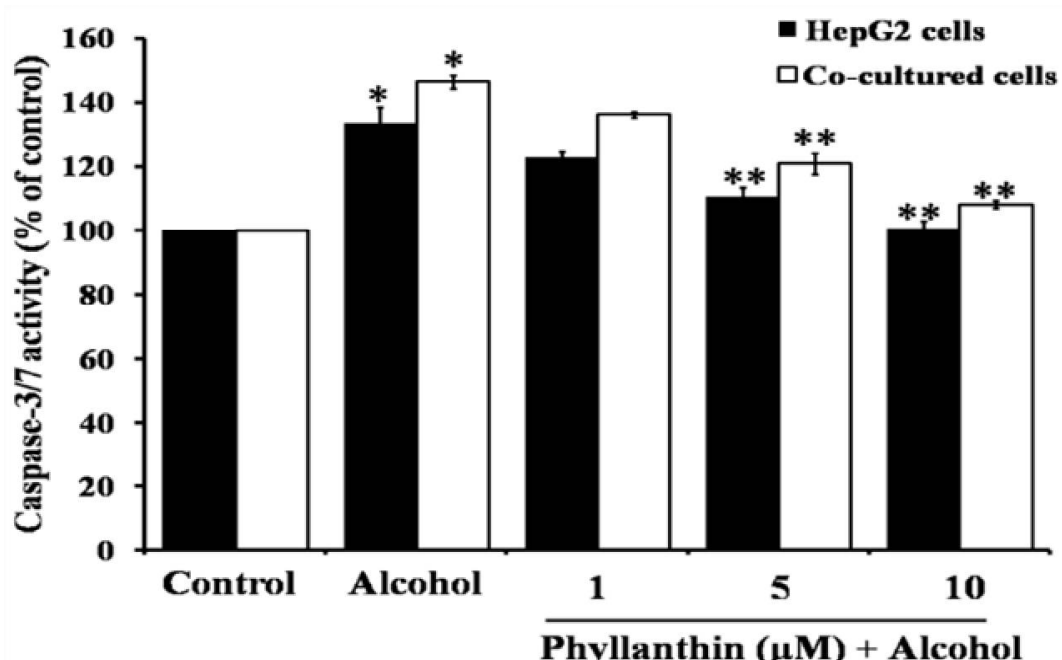

Figure 5: Effect of alcohol on the activation of caspase-3/7 activity and its inhibition by phyllanthin pretreatment in HepG2 cells and co-cultured cells. HepG2 cells cultured alone and co-cultured with THP-1 differentiated macrophage cells were pretreated with 1,5 and $10 \mu \mathrm{M}$ of phyllanthin for $24 \mathrm{~h}$ before exposure to alcohol for $4 \mathrm{~h}$. Caspase-3/7 activity was determined by Capase-Glo assay kit. Data shown are mean \pm SEM of four independent experiments; ${ }^{*} p<0.001$ compared to control; ${ }^{* *} p<0.001$ compared to alcohol

\section{Effect of phyllanthin against alcohol-induced apoptosis in HepG2 and co-cultured cells}

Alcohol exposure significantly increased in the percentage of apoptotic and necrotic cells in the HepG2 cells (Figure 4A). In addition, there was a significant increase in the caspase- $3 / 7$ activation when compared with the untreated cells (Figure 5). Surprisingly, exposure to a high concentration of alcohol showed a stronger activity to diminish the viable cells by inducing apoptosis and necrotic cell death in the co-cultured cells than HepG2 (Figure 4B and Figure 5). These data indicated that macrophages were involved in the severity of alcohol-induced liver cell death. However, phyllanthin at 1,5 and $10 \mu \mathrm{M}$ caused a decrease in the percentage of apoptotic and necrotic cells (Figure 4A and 4B) and also significantly inhibited caspase- $3 / 7$ activation by alcohol in both HepG2 cells and the co-cultured cells (Figure 5). These results indicated that phyllanthin had an anti-apoptotic activity against alcohol-induced toxicity in both cell types. Taken together, these finding indicated that phyllanthin attenuated necrosis in both cell types.

\section{DISCUSSION}

Phyllanthin has anti-oxidative activity, antiinflammatory activity $[9,10,17]$ and protects against alcohol-induced liver injury via its antioxidant properties [12]. Our MTT assay showed that alcohol exposure significantly reduced cell viability and altered the morphology (the cells rounded up, lose contact with their neighbors and shrank) of the HepG2 single cell cultures and also when co-cultured with THP-1 differentiated macrophage cells and that this 
corresponded to the increase in intracellular ROS production. Alcohol-induced oxidative stress plays a major role in the mechanism by which alcohol is involved in liver injury [18] and it triggers cellular damage in various tissues including the brain, liver and retina $[12,19,20]$.

The advancement of alcohol-induced liver injury involves both parenchymal and non-parenchymal cells of the liver. Hence macrophages could make hepatocytes more susceptible to alcohol injury by increasing the production of ROS [21]. However, pretreatment with phyllanthin prevented the production of ROS induced by alcohol in both HepG2 cells and co-cultured cells. This result is consistent with a previous finding of decreased oxidative stress to chemicalinduced toxicity of hepatocyte cells after phyllanthin treatment $[9,12]$. In addition, phyllanthin had a strong inhibitory activity on the increase in production of nitric oxide radical by macrophages [10] and oxidative burst in neutrophils [22]. The residues produced by ROS caused a lowering of the MMP leading to an uncontrolled ROS formation and release of proapoptotic factors such as cytochrome $\mathrm{c}$ into the cytosol where they promote activation of caspase $[23,24]$ and subsequently apoptosis.

In the present study, alcohol caused a significant decrease in the MMP that led to a more profound reduction in the co-cultured cells than the HepG2 culture alone, presumably because of the involvement of ROS in the destruction of the MMP. Also, this finding is consistent with a previous observation that acute alcohol treatment induced apoptosis in primary hepatocytes accompanied by ROS production and mitochondrial depolarization $[25,26]$. In the current study, pretreatment with phyllanthin impeded the decrease of MMP in the HepG2 cells and the co-cultured cells. This can partly explain the hepatoprotective potential of phyllanthin that may maintain the normal redox status and improve mitochondrial function.

Cells undergoing apoptosis present several characteristic morphological and molecular changes [27]. Chromatin condensations, membrane blebbing, phosphatidylserine externalization, DNA fragmentation and, eventually, the disruption of the cell into membrane-bound fragments are some of the distinct morphological and biochemical features [28] associated with apoptosis.

Acute alcohol exposure promotes apoptosis in primary hepatocyte cultures that was linked with ROS formation, mitochondrial depolarization, and cytochrome c release [25]. In this study, alcohol exposure induced a higher severity of liver toxicity by both apoptotic and necrotic cell death in co-culture with THP-1 differentiated macrophage cells than in HepG2 cells alone. Macrophage cells may also, in part, be involved in the severity of alcohol-induced co-cultured cell death. Several reports have indicated that there is a relationship between Kupffer cells and the severity of alcohol-induced liver damage $[29,30]$.

After being activated, macrophage cells secrete a category of cytokines such as TNF- $\alpha$, interleukin one beta and thus the activated macrophage cells are the main source of ROS in the liver [5,29-31]. These inflammatory mediators lead to hepatocyte dysfunction, apoptosis and necrosis of hepatocytes, and the production of extracellular matrix proteins contributing to characteristic fibrosis $[30,31]$.

Considering these results, pretreating cells with phyllanthin was effective in inhibiting alcoholinduced cell death by inhibiting caspase-3/7 activation and also by decreasing the number of apoptotic and necrotic cells in the HepG2 cells alone and the co-cultured cells. Meanwhile, a $P$. amarus extract decreased DNA fragmentation in acetic acid-induced colitis in rats [11]. In addition, there is some evidence that phyllanthin inhibited TNF- $\alpha$ expression and prevented activation of the nuclear factor-KB in hepatic tissue [32]. Thus, the finding in this study clearly support the antiapoptotic role of phyllanthin, the mechanism of which was to ameliorate the disturbances caused by oxidative stress and loss of mitochondrial function, with inhibition of the subsequent apoptosis cascade.

\section{CONCLUSION}

Alcohol-induced liver cell death is caused by increased ROS generation, decreased MMP and induced caspase-3/7 activation in both HepG2 cells and those co-cultured with THP-1 differentiated macrophage cells. Phyllanthin prevents alcohol-induced cell death in human liver cells by decreasing the production of ROS and increasing MMP change and as well as by inhibiting the activation of caspase-3/7 activity. These results suggest that phyllanthin can be developed for hepatoprotective therapy against alcohol-induced liver disease.

\section{ACKNOWLEDGEMENT}

This study was supported by Prince of Songkla University (no. SCl550419S), Songkhla, Thailand. The authors thank $\mathrm{Dr}$ Wisit Tangkeangsirisin for providing HepG2 cells, Dr 
Hemvala Chirdchupunseree for providing phyllanthin, and Dr Brian Hodgson for assistance with English language editing of the manuscript.

\section{CONFLICT OF INTEREST}

No conflict of interest associated with this work.

\section{CONTRIBUTION OF AUTHORS}

We declare that this work was done by the authors named in this article and all liabilities pertaining to claims relating to the content of this article will be borne by the authors.

\section{REFERENCES}

1. Altamirano J, Bataller $R$. Alcoholic liver disease: pathogenesis and new targets for therapy. Nat Rev Gastroenterol Hepatol 2011; 8: 491-501.

2. Natori S, Rust C, Stadheim LM, Srinivasan A, Burqart LJ, Gores GJ. Hepatocyte apoptosis is a pathologic feature of human alcoholic hepatitis. J Hepatol 2001; 34: 248253.

3. Wang K. Molecular mechanisms of hepatic apoptosis. Cell Death Dis 2014; 5: e996.

4. Roberts RA, Ganey PE, Ju C, Kamendulis LM, Rusyn I, Klaunig JE. Role of the Kupffer cell in mediating hepatic toxicity and carcinogenesis. Toxicol Sci 2007; 96: 2-15.

5. Mandrekar P, Ambade A, Lim A, Szabo G, Catalano D. An essential role for monocyte chemoattractant protein1 in alcoholic liver injury: regulation of proinflammatory cytokines and hepatic steatosis in mice. Hepatology 2011; 54: 2185-2197.

6. Ziol M, Tepper M, Lohez M, Arcangeli G, Ganne N, Christidis C, Trinchet JC, Beaugrand M, Guillet JG, Guettier C. Clinical and biological relevance of hepatocyte apoptosis in alcoholic hepatitis. I Hepatol 2001; 34: 254-260.

7. Jaeschke $H$. Inflammation in response to hepatocellular apoptosis. Hepatology 2002; 35: 964-966.

8. Syamasundar KV, Singh B, Thakur RS, Husain A, Kiso $Y$, Hikino $H$. Antihepatoprotective principles of Phyllanthus niruri herbs. J Ethnopharmacol 1985; 14: 41-44.

9. Krithika R, Mohankumar R, Verma RJ, Shrivastav PS, Mohamad IL, Gunasekaran P, Narasimhan S. Isolation, characterization and antioxidative effect of phyllanthin against CCl4-induced toxicity in HepG2 cell line. Chem Biol Interact 2009; 181: 351-358.

10. Fang SH, Rao YK, Tzeng YM. Anti-oxidant and antiinflammatory mediator's growth inhibitory effects of compounds isolated from Phyllanthus urinaria. $J$ Ethnopharmacol 2008; 116: 333-340.

11. Kandhare $A D$, Ghosh $P$, Ghule $A E$, Zambare GN, Bodhankar SL. Protective effect of Phyllanthusamarus by modulation of endogenous biomarkers and DNA damage in acetic acid induced ulcerative colitis: role of phyllanthin and hypophyllanthin. Apollo Med 2013; 10: 87-97.

12. Chirdchupunseree $H$, Pramyothin P. Protective activity of phyllanthin in ethanol-treated primary culture of rat hepatocytes. J Ethnopharmacol 2010; 128: 172-176.

13. Krithika $R$, Verma RJ, Shrivastav $P S$, Suguna $L$. Phyllanthin of standardized Phyllanthus amarus extract attenuates liver oxidative stress and exerts cytoprotective activity on human hepatoma cell line. J Clin Exp Hepatol 2011; 1: 57-67.

14. Kosaka C, Masuda J, Shimokado K, Zen K, Yokota T, Sasaguri T, Ogata J. Interferon-y suppresses PDGF production from THP-1 cells and blood monocytederived macrophages. Atherosclerosis 1992; 97: 75-87.

15. Mosmann T. Rapid colorimetric assay for cellular growth and survival: application to proliferation and cytotoxicity assays. J Immunol Methods 1983; 65: 55-63.

16. Wang $H$, Joseph JA. Quantifying cellular oxidative stress by dichlorofluorescein assay using microplate reader. Free Radic Biol Med 1999; 27: 612-616.

17. Harish R, Shivanandappa T. Antioxidant activity and hepatoprotective potential of Phyllanthus niruri. Food Chem 2006; 95: 180-185.

18. Cederbaum Al, Lu Y, Wu D. Role of oxidative stress in alcohol-induced liver injury. Arch Toxicol 2009; 83: 519548.

19. Olney JW, Tenkova T, Dikranian K, Muglia LJ, Jermakowicz WJ, D'Sa C, Roth KA. Ethanol-induced caspase-3 activation in the in vivo developing mouse brain. Neurobiol Dis 2002; 9: 205-219.

20. Flores-Bellver M, Bonet-Ponce L, Barcia JM, GarciaVerdugo JM, Martinez-Gil N, Saez-Atienzar S, SanchoPelluz J, Jordan J, Galindo MF, Romero FJ. Autophagy and mitochondrial alterations in human retinal pigment epithelial cells induced by ethanol: implications of 4hydroxy-nonenal. Cell Death Dis 2014; 5: e1328.

21. Barnes MA, McMullen MR, Roychowdhury S, Pisano SG, Liu X, Stavitsky AB, Bucala R, Nagy LE. Macrophage migration inhibitory factor contributes to ethanol-induced liver injury by mediating cell injury, steatohepatitis, and steatosis. Hepatology 2013; 57: 1980-1991.

22. Yuandani, llangkovan M, Jantan I, Mohamad HF, Husain $K$, Razak AFA. Inhibitory effects of standardized extracts of Phyllanthus amarus and Phyllanthus urinaria and their marker compounds on phagocytic activity of human neutrophils. Evid Based Complement Alternat Med 2013; doi: 10.1155/2013/603634.

23. Malhi H, Guicciardi EM, Gores GJ. Hepatocyte death: a clear and present danger. Physiol Rev 2010; 90: 11651194.

24. Sinha K, Das J, Pal PB, Sil PC. Oxidative stress: the mitochondria-dependent and mitochondria-independent pathways of apoptosis. Arch Toxicol 2013; 87: 11571180.

25. Higuchi $H$, Adachi M, Miura S, Gores GJ, Ishii $H$. The mitochondrial permeability transition contributes to acute ethanol-induced apoptosis in rat hepatocytes. Hepatology 2001; 34: 320-328.

Trop J Pharm Res, May 2016; 15(5): 987 
26. Chen CC, Liou SW, Chen CC, Chen WC, Hu FR, Wang IJ, Lin SJ. Coenzyme Q10 rescues ethanol-induced corneal fibroblast apoptosis through the inhibition of caspase-2 activation. J Biol Chem 2013; 17: 1168911704.

27. Strasser A, O'Connor L, Dixit VM. Apoptosis signaling. Annu Rev Biochem 2002; 69: 217-245.

28. D'Emilio A, Biagiotti L, Burattini S, Battistelli M, Canonico B, Evangelisti C, Ferri P, Papa S, Martelli AM, Falcieri E. Morphological and biochemical patterns in skeletal muscle apoptosis. Histol Histopathol 2010; 25: 21-32.

29. Nanji AA. Role of kupffer cells in alcoholic hepatitis. Alcohol 2002; 27: 13-15.
30. Barnes MA, Roychowdhury S, Nagy LE. Innate immunity and cell death in alcoholic liver disease: role of cytochrome P4502E1. Redox Biol 2014; 2: 929-935.

31. Barnes MA, McMullen MR, Roychowdhury S, Pisano SG, Liu X, Stavitsky AB, Bucala R, Nagy LE. Macrophage migration inhibitory factor contributes to ethanol-induced liver injury by mediating cell injury, steatohepatitis, and steatosis. Hepatology 2013; 57: 1980-1991.

32. Krithika R, Jyothilakshmi V, Verma RJ. Phyllanthin inhibits CCl4-mediated oxidative stress and hepatic fibrosis by down-regulating TNF- $\alpha / N F-K B$ and profibrotic factor TGF- $\beta 1$ mediated inflammatory signaling. Toxicol Ind Health 2014; doi: 10. $1177 / 0748233714532996$ 